\title{
Adverse reactions of fluorescein angiography: a prospective study
}

\author{
Reações adversas na angiofluoresceinografia:estudoprospectivo
}

\author{
Rodrigo Pessoa Cavalcanti Lira ${ }^{1}$ \\ Cleriston Lucena de Andrade Oliveira ${ }^{2}$ \\ Marta Virgínia Ribeiro Brito Marques $^{3}$ \\ Alaine Rocha Silva ${ }^{4}$ \\ Cristiano de Carvalho Pessoa ${ }^{5}$
}

Trabalho realizado na Universidade Estadual de Campinas - UNICAMP e na Universidade Federal de Pernambuco.

${ }^{1}$ Doutor pela Universidade Estadual de Campinas UNICAMP - Campinas (SP) - Brasil. Preceptor do Curso de Especialização em Oftalmologia da Universidade Federal de Pernambuco - UFPE - Recife (PE) - Brasil.

${ }^{2}$ Especialista em Oftalmologia pelo Conselho Brasileiro de Oftalmologia.

${ }^{3}$ Especialista em Oftalmologia pelo Conselho Brasileiro de Oftalmologia.

${ }^{4}$ Graduanda em Enfermagem pela Faculdade Maurício de Nassau - Recife (PE) - Brasil.

Especialista em Oftalmologia pelo Conselho Brasileiro de Oftalmologia.

Endereço para correspondência: Rodrigo Pessoa Cavalcanti Lira. Rua Aquarius, 76 - Apto. 1403 - Recife (PE) CEP 52011-020

E-mail: rodrigopclira@hotmail.com

Recebido para publicação em 21.08.2006

Última versão recebida em 28.02.2007

Aprovação em 22.04.2007

\section{ABSTRACT}

Purposes: To determine both the incidence of adverse reactions in patients who underwent fluorescein angiography for the first time and to determine whether systemic arterial hypertension, diabetes or allergy history increases the chance of reaction to intravenous fluorescein. Methods: Data collection was carried out between January 2001 and October 2002 in Recife, Brazil. Patients with prior fluorescein angiography history, pregnant patients or patients in use of corticosteroids, immunosuppressive or antihistamine drugs were excluded. Results: Out of 1,500 enrolled patients, 1,039 (69.3\%) underwent the test for the first time. The mean age was $58 \pm 16$ years and the median age was 60 years. Of these, 628 $(60.4 \%)$ were women. Nausea occurred in $71(6.83 \%)$ patients, vomiting in $14(1.35 \%)$, urticaria in $11(1.06 \%)$, bronchospasm in $4(0.38 \%)$ and laryngeal edema in $1(0.01 \%)$. Five patients presented more than one adverse reaction. Higher incidences of adverse reactions were observed in diabetic patients $[\mathrm{p}<0.002, \mathrm{RR}=1.80(\mathrm{CI}=1.24-2.60)]$, patients with systemic arterial hypertension $[\mathrm{p}<0.002, \mathrm{RR}=1.84(\mathrm{CI}=1.26-2.71)]$ and patients with allergy history $[\mathrm{p}<0.001, \mathrm{RR}=3.90(\mathrm{CI}=2.70-5.63)]$. Conclusions: A cumulative incidence of $9.72 \%$ adverse reactions was observed in patients who had undergone this test for the first time. The presence of the allergy history, diabetes or systemic arterial hypertension increased the incidence of adverse reactions to the dye.

Keywords: Fluorescein angiography; Anaphylaxis; Drug hypersensitivity; Adverse reactions

\section{INTRODUCTION}

Fluorescein dye was initially synthesized by Adolf von Baeyer in $1871^{(1)}$. Novotny and Alvis developed a photographic system for sequential documentation of fluorescein flow through the ocular fundus in $1960^{(2)}$.

Fluorescein angiography is a diagnostic technique used in the interpretation of ocular pathologic states. It allows sequential visualization of blood flow simultaneously through retinal, choroidal and iris tissues ${ }^{(3)}$. In wide use for over 40 years, it is a valuable tool in the study, the understanding, and the treatment of ocular diseases ${ }^{(3-4)}$.

This is considered a relatively safe procedure, although numerous adverse reactions have been reported in the literature. These are divided into mild (nausea, vomiting, pruritus, sneezing, vaso-vagal disorders, inadvertent arterial injection), moderate (urticaria, other skin eruptions, syncope, thrombophlebitis, pyrexia, local tissue necrosis, muscular paralysis) and severe (bronchospasm, laryngeal edema, circulatory shock, myocardial infarction, tonic-clonic seizure $)^{(5-7)}$. 
Previous studies indicate that the most frequent adverse reactions are mild, such as nauseas and vomiting (2\% to $14 \%)$ and that moderate and severe reactions are infrequent $(<1 \%)^{(5-6,8)}$. The reported frequency of these adverse reactions has varied among authors, however most of the studies are retrospective and they do not distinguish patients who had previously undergone this test from those who had undergone it for the first time ${ }^{(7,9-10)}$.

The exact mechanism of adverse reactions in fluorescein angiography is not clearly understood. Some proposed mechanisms include: histamine release of non-allergic nature in the absence of antigen-antibody reaction (anaphylactoid reactions); vaso-vagal phenomenon resulting in bradycardia, arterial hypotension and reduced cardiovascular perfusion; drug allergy of the immediate hypersensitivity type (anaphylactic reactions); anxiety-related medullary sympathetic discharge, eliciting tachycardia and myocardial stress; direct vasospastic toxic effect of intravenous injection; effect of contamination during manufacture of the drug; direct systemic effect of topical mydriatics, particularly phenylephrine; or any combination of the above potential factors ${ }^{(7)}$.

Retinal complications of hypertensive and diabetic retinopathy are the main diseases that motivate request for this test ${ }^{(11-12)}$. Some authors report that allergy history, systemic arterial hypertension $(\mathrm{SAH})$ and diabetes increase the risk of adverse reactions to fluorescein injection ${ }^{(8-9)}$.

The purposes of this prospective study are both to determine the incidence of adverse reactions in patients who had undergone fluorescein angiography for the first time, and to determine if $\mathrm{SAH}$, diabetes or allergy history increase the chance of reaction to intravenous fluorescein.

\section{METHODS}

\section{Patients and medical procedures}

The study was performed in Recife, Brazil. This eye clinic has a demand predominantly consisting of private patients from the metropolitan region of Recife, performing annually 900 fluorescein angiographies. It is a referral center for retina diseases with two specialists.

Data collection was carried out between January 2001 and October 2002 in Recife, Brazil. Patients with prior fluorescein angiography history, pregnant patients or patients in use of corticosteroids, immunosuppressive or antihistamine drugs were excluded. The study was approved by the local ethics committee and by the ethics committee of the Federal University of Pernambuco (CONEP number 0150.0.172.000-06). All patients filled out a written consent.

Sodium fluorescein $20 \%{ }^{\circledR}$ (Ophthalmos) was used in a single $2.5 \mathrm{ml}$ dose, injected into the cubital vein, with a manual infusion speed of approximately $1 \mathrm{ml}$ per second. The images were caught through a Topcon Retinal Camera ${ }^{\circledR} 50$ FX with the aid of a digital program (Ophthalmic System Image).

Medical preoperative evaluation was performed one hour before the test by an anesthesiologist. It consisted of anamnesis and physical examination. Twenty-two patients were not allowed to undergo the angiogram because they presented a systemic arterial pressure higher than 160/110 $\mathrm{mmHg}$.

\section{Data Collection}

Anamnesis and physical examination were collected on a specific form completed by the anesthesiologist at the time of the clinical examination. Adverse reactions that occurred during and after the angiography were registered in a standardized form by the ophthalmologist.

The definitions of adverse reactions to fluorescein registered at this study were based on the literature ${ }^{(7)}$. Local dye leaking was not included among the adverse reactions for being considered inherent to the application technique and not a systemic clinical reaction to the dye. Reactions that occurred up to 24 hours after dye injection were considered related to the test. Twenty-four hours following eye clinic discharge, all patients were asked by phone interview about medical events within this period.

Patients considered with allergy history were those with a report of anaphylactic or anaphylactoid reactions to specific substances, individuals with bronchial asthma, allergic rhinitis or urticaria. The definitions of SAH and diabetes were those adopted in the literature ${ }^{(13)}$.

\section{Sample size and statistical analysis}

A sample of 1,000 patients who were submitted to the fluorescein angiography for the first time was planned. It was assumed that $30 \%$ of the tests were in patients who had previously undergone fluorescein angiography, and then a total of 1,500 tests were performed during a period of one year and nine months.

As parameters for central trend and dispersion for data, mean, pattern deviation and median were determined. For categorical variables, chi-square test, relative risk and confidence interval of $95 \%$ were calculated; for continuous variables, Student's $t$ test was used. Results of these analyses were considered statistically significant if $P$ values were $<0.05$.

\section{RESULTS}

Of the 1,500 enrolled patients, $461(30.7 \%)$ had already undergone fluorescein angiography and 1,039 (69.3\%) underwent this test for the first time. Subsequent analyses of this study mentioned the latter in an exclusive way.

The mean age was $58 \pm 16$ years and the median age was 60 years. Sixty hundred-twenty-eighty $(60.4 \%)$ patients were female and $411(39.6 \%)$ male. Four hundred ninety-two (47.3\%) patients had SAH, $376(36.2 \%)$ diabetes and $211(20.3 \%)$ an allergy history.

The incidence of adverse reactions to the dye was $9.24 \%$ (96 patients). Mild reactions occurred in $85(8.18 \%)$ patients [nauseas in $71(6.83 \%)$ and vomiting in $14(1.35 \%)$ ], moderate 
reactions in $11(1.06 \%)$ patients (urticaria) and severe reactions in $5(0.48 \%)$ patients [bronchospasm in $4(0.38 \%)$ and laryngeal edema in $1(0.1 \%)$ ]. The cumulative incidence of adverse reactions was $9.72 \%$ (101 patients) because five subjects presented more than one adverse reaction. Four patients had urticaria and bronchospasm and one had urticaria and laryngeal edema, all of which are considered anaphylactoid reactions. No reaction occurred within the 24 -hour period after the patient had left the eye clinic.

The mean age of patients who presented reactions to fluorescein was $57.2 \pm 12.5$ years and for those who had no reaction it was of $59.0 \pm 15.4$ years $(p<0.273)$. Among the former, $56(58.3 \%)$ were women, while among the latter, 572 $(60.6 \%)$ were women $(\mathrm{p}<0.657)$.

A higher incidence of adverse reactions was observed in patients with diabetes $[\mathrm{p}<0.002, \mathrm{RR}=1.80(\mathrm{CI}=1.24-2.60)], \mathrm{SAH}$ $[\mathrm{p}<0.002, \mathrm{RR}=1.84(\mathrm{CI}=1.26-2.71)]$ and allergy history $[\mathrm{p}<0.001$, $\mathrm{RR}=3.90(\mathrm{CI}=2.70-5.63)]($ Table 1$)$.

\section{DISCUSSION}

Almost all patients with ocular problems are exposed to fluorescein, in topical form, during routine ocular examination. However, the report of adverse reactions is rare. In case of oral administration of fluorescein, the frequency of reactions is between $1 \%$ and $2 \%{ }^{(14-16)}$ and in case of intravenous dye it is between $3 \%$ and $20 \% \%^{(4-8,17-18)}$. In this study, the cumulative incidence of adverse reactions to dye injection was $9.72 \%$ in patients who were submitted to fluorescein angiography for the first time.

Mild reactions as nausea and/or vomiting occurred in $8.18 \%$ of the patients. In other studies, they ranged from $3 \%$ to $14 \%^{(6,9,19-20)}$. The pathophysiology of these effects involves the activation of chemical receptors in the vomiting nervous center located in the area postrema that function as primary detectors of emetic stimulation and induce vomiting through integration with vagal nerve or vestibular system ${ }^{(21)}$.

Moderate and/or severe reactions as urticaria, bronchospasm and laryngeal edema were infrequent, with incidences of $1.06 \%, 0.38 \%$ and $0.1 \%$, respectively. Other authors report fre- quencies of urticaria between $0.5 \%$ and $1.2 \%(6-7,10)$ and of respiratory distress between $0.02 \%$ and $0.1 \%{ }^{(7-8,19)}$. Such reactions can be explained by different pathophysiologic mechanisms; however they are probably of the anaphylactoid type, characterized by independent IgE mechanisms that involve direct activation of mast cells, activation of complement system and alterations in arachidonic acid metabolism ${ }^{(22-23)}$. Skin tests with fluorescein have no predictive value and it is useless to perform them since the reaction mechanism is not IgE-mediated, and thus they reinforce the above described pathophysiology ${ }^{(24-25)}$.

Death as result of the test was not observed in this study, though it may occur very rarely. There are reports of one for each 200,000 patients, but with controversies of the direct relation to test performance ${ }^{(7,10,26-28)}$.

Gender did not show itself as a statistically significant factor for the presence of adverse reactions $(\mathrm{p}<0.657)$. Patients with $\mathrm{SAH}[\mathrm{p}<0.002, \mathrm{RR}=1.84(\mathrm{CI}=1.26-2.71)]$ or diabetes $[\mathrm{p}<0.002, \mathrm{RR}=1.80(\mathrm{CI}=1.24-2.60)]$ presented higher incidence of adverse reactions, mainly of the mild type. There is no definitive reason for this association; a presumable mechanism is the predisposition of these groups to vaso-vagal reactions because of neurovegetative system instability $(7,9)$.

Patients with an allergy history $[\mathrm{p}<0.001, \mathrm{RR}=3.90(\mathrm{CI}=2.70$ 5.63)] also presented higher incidence of adverse reactions to the test. Possibly this is due to the fact that atopic patients have immunologic mechanisms in its etiopathophysiologies, mainly reactions of the immediate hypersensitivity type ${ }^{(29)}$.

A possible limitation of this study was the use of $25 \%$ fluorescein, while some of the studies used $10 \%$ fluorescein. However, in the literature, difference in the incidence or severity of adverse reactions between $10 \%$ and $25 \%$ concentrations ${ }^{(7,30)}$ was not observed.

\section{CONCLUSIONS}

A cumulative incidence of $9.72 \%$ of adverse reactions was observed in patients who had undergone this test for the first time. The presence of allergy history, diabetes or SAH increased the incidence of adverse reactions to the dye.

\begin{tabular}{|c|c|c|c|c|c|c|c|c|}
\hline \multirow{3}{*}{$\begin{array}{l}\text { Coexistent } \\
\text { disease } \\
\text { (N) }\end{array}$} & \multicolumn{5}{|c|}{ Adverse reactions } & \multirow[b]{3}{*}{ Total } & \multirow[b]{3}{*}{$\boldsymbol{P}$} & \multirow{3}{*}{$\begin{array}{c}\text { Relative risk } \\
(95 \% \mathrm{Cl})^{\dagger}\end{array}$} \\
\hline & \multicolumn{2}{|c|}{ Mild } & \multirow{2}{*}{$\frac{\text { Moderate }}{\text { Urticaria }}$} & \multicolumn{2}{|c|}{ Severe } & & & \\
\hline & Nausea & Vomiting & & $\begin{array}{c}\text { Broncho- } \\
\text { spasm }\end{array}$ & $\begin{array}{c}\text { Laryngeal } \\
\text { edema }\end{array}$ & & & \\
\hline SAH (492) & 45 & 9 & 8 & 0 & 1 & 63 & $0.002^{*}$ & $1.84(1.26-2.71)$ \\
\hline Without SAH (547) & 26 & 5 & 3 & 4 & 0 & 38 & & \\
\hline Diabetes (376) & 35 & 7 & 8 & 0 & 1 & 51 & $0.002^{*}$ & $1.80(1.24-2.60)$ \\
\hline Allergy (115) & 20 & 4 & 8 & 0 & 1 & 33 & $0.001^{*}$ & $3.90(2.70-5.63)$ \\
\hline Without Allergy (924) & 51 & 10 & 3 & 4 & 0 & 68 & & \\
\hline
\end{tabular}




\section{RESUMO}

Objetivos: Determinar a incidência de reações adversas em pacientes submetidos à angiofluoresceinografia pela primeira vez e determinar se hipertensão arterial sistêmica, diabetes ou história de alergia aumentam a chance de reações à fluoresceína intravenosa. Métodos: Os dados foram coletados entre janeiro de 2001 e outubro de 2002 em Recife, Brasil. Pacientes com angiofluoresceinografia prévia, gestantes ou pacientes em uso de medicamentos corticosteróides, imunossupressores ou antihistamínicos foram excluídos. Resultados: Dos 1.500 pacientes iniciais, $1.039(69,3 \%)$ realizavam o exame pela primeira vez. A idade média foi de $58 \pm 16$ anos e a mediana de 60 anos. Dentre esses, $628(60,4 \%)$ pessoas eram do sexo feminino. Náusea ocorreu em $71(6,83 \%)$ pacientes, vômito em 14 (1,35\%), urticária em $11(1,06 \%)$, broncoespasmo em $4(0,38 \%)$ e edema de laringe em $1(0,01 \%)$. Cinco pacientes apresentaram mais de uma reação adversa. Maiores incidências de reações adversas foram observadas em diabéticos $[\mathrm{p}<0,002, \mathrm{RR}=1,80(\mathrm{IC}=1,24-2,60)]$, hipertensos $[\mathrm{p}<0,002, \mathrm{RR}=1,84$ ( $\mathrm{IC}=1,26-2,71)]$ e pacientes com história de alergia $[\mathrm{p}<0,001, \mathrm{RR}=3,90(\mathrm{IC}=2,70-5,63)]$. Conclusões: Uma incidência cumulativa de $9,72 \%$ de reações adversas foi observada em pacientes submetidos à angiofluoresceinografia pela primeira vez. Presença de história de alergia, diabetes ou hipertensão arterial aumentou a incidência de reações adversas ao contraste.

Descritores: Angiofluoresceinografia; Anafilaxia; Hipersensibilidade a medicamentos; Reações adversas

\section{REFERENCES}

1. von Baeyer A. Uber ein neue Klasse von Farbstoffen. Ber Deut Chem Ges. $1871 ; 4: 555$.

2. Novotny HR, Alvis DL. A method of photographing fluorescein in circulating blood in the human retina. Circulation. 1961;24:82-6.

3. Berkow JW, Flower RW, Orth DH, Kelley JS. Fluorescein and Indocyanine Green Angiography: techniques and interpretation. $2^{\text {nd }}$ ed. San Francisco: The Foundation of the American Academy of Ophthalmology; 1997. p.224.

4. Alvis DL. Twenty-fifth anniversary of fluorescein angiography. Arch Ophthalmol. 1985;103:1269.

5. Stein MR, Parker CW. Reactions following intravenous fluorescein. Am J Ophthalmol. 1971;72:861-8.

6. Kwiterovich KA, Maguire MG, Murphy RP, Schachat AP, Bressler NM,
Bressler SB et al. Frequency of adverse systemic reactions after fluorescein angiography: results of a prospective study. Ophthalmology. 1991;98:1139-42.

7. Yannuzzi LA, Rohrer KT, Tindel LJ, Sobel RS, Costanza MA, Shields W et al. Fluorescein angiography complication survey. Ophthalmology. 1986;93:611-7.

8. Karhunen U, Raitta C, Kala R. Adverse reactions to fluorescein angiography. Acta Ophthalmol. 1986;64:282-6.

9. Lepri A, Salvini R, Rizzo L, Cetica P, Grechi S, Di Filippo A et al. Accidenti durante angiografia retinica con fluoresceina. Minerva Anesthesiol. 1997;63:133-40.

10. Lacava AC, Leal EB, Caballero JC, Medeiros OA. Angiografia fluoresceínica e suas complicações, relato de 1 caso de óbito. Rev Bras Oftalmol. 1996,55(1):59-62.

11. Lucena DR, Siqueira RC. Os dez mais freqüentes diagnósticos angiofluoresceinográficos de um serviço de referência em retina e vítreo. Rev Bras Oftalmol. 2000;59(8):594-6.

12. Veloso JCB, Ventura AG, Escarião PHG, Leite Neto AQ, Dias S. Angiofluoresceinografia em serviço de referência. An Fac Med Univ Fed Pernamb. 2001; 46(1):45-7.

13. Tierney Jr LM, McPhee SJ, Papadakis MA. Current medical diagnosis and treatment. $38^{\text {th }}$ ed. Connecticut: Appleton \& Lange; 2001. p.1872.

14. Nayak BK, Ghose S. A method for fundus evaluation in children with oral fluorescein. Br J Ophthalmol. 1987;71:907-9.

15. Kinsella KP, Mooney DJ. Anaphylaxis following oral fluorescein angiography. Am J Ophthalmol. 1988;106:745-6.

16. Hara T, Inami M, Hara T. Efficacy and safety of fluorescein angiography with orally administered sodium fluorescein. Amer J Ophthalmol. 1998;126:560-4.

17. Patz A, Finkelstein D, Fine SL, Murphy RP. The role of fluorescein angiography in national collaborative studies. Ophthalmology. 1986;93:1466-70.

18. Singerman LJ. Fluorescein angiography: Practical role in the office management of macular diseases. Ophthalmology. 1986;93:1209-15.

19. Butner RW, McPherson AR. Adverse reactions in intravenous fluorescein angiography. Ann Ophthalmol. 1983;15:1084-5.

20. Brown Jr RE, Sabates R, Drew SJ. Metoclopramide as prophylaxis for nausea and vomiting induced by fluorescein. Arch Ophthalmol. 1987;105:658-9.

21. Andrews PL. Physiology of nausea and vomiting. British Journal of Anaesth. 1992;69(suppl.1):2S-19S.

22. Imbeloni LE, Manhães WL. Reações anafiláticas e anafilactóides. Rev Bras Anest. 1996,19:226-7.

23. Seba J, Castro FFM. Reações adversas a fluoresceína: Reação anafilática ou anafilactóide?. Rev Bras Alergia Imunopatol. 1996;19:226-7.

24. Trindade-Porto C, Alonso-Llamazares A, Robledo T, Chamorro M, Dominguez J, Plaza A, Martinez-Cócera C. Fluorescein-induced adverse reaction. Allergy. 1999,54:1230.

25. Rohr AS, Pappano Jr. JE. Prophylaxis against fluorescein-induced anaphylactoid reactions. J Allergy Clin Immunol. 1992;90:407-8

26. Zorografos L. Enquête internationale sur incidence dês accidentis graves ou fatals pouvant survenir lors d'une angiographie fluorescéinique. Klin Monatsbl Augenheilkd. 1983;182:460-2.

27. Junior JH. Riscos da angiografia fluoresceínica. Arq Bras Oftalmol. 1981;44:99-100.

28. Hitosugi M, Omura K, Yokoyama T, Kawato H, Motozawa Y, Nagai T et al. An autopsy case of fatal anaphylactic shock following fluorescein angiography: a case report. Med Sci Law. 2004;44(3):264-5.

29. Kumar V, Abbas AK, Fausto N. Robbins \& Cotran Pathologic Basis of Disease. $7^{\text {th }}$ ed. San Francisco: WB Saunders Company; 2005. p.1552.

30. Justice J Jr, Paton D Beyrer CR, Seddon GG. Clinical comparison of 10 percent and 25 percent intravenous sodium fluorescein solutions. Arch Ophthalmol. 1977;95(11):2015-6. 